\title{
The significance of cortisol on acclimation to salinity in pejerrey Odontesthes bonariensis
}

\author{
[Importância do cortisol na aclimatação a salinidade em \\ peixe-rei Odontesthes bonariensis] \\ M.Y. Tsuzuki ${ }^{1}$, K. Ogawa ${ }^{1}$; C.A. Strüssmann ${ }^{1}$, M. Maita ${ }^{1}$, F. Takashima ${ }^{1}$, C.M.R. Melo ${ }^{2}$ \\ ${ }^{1}$ Tokyo University of Marine Science and Technology - Faculty of Marine Science \\ Department of Marine Biosciences - Tokyo, Japan \\ ${ }^{2}$ Departamento de Aqüicultura - CCA-UFSC \\ Caixa Postal 476 \\ 88040-970 - Florianópolis, SC
}

\begin{abstract}
The role of cortisol on the osmoregulation of pejerrey Odontesthes bonariensis at different salinities was investigated in adult fish injected with $0.7 \mathrm{mg}$ hydrocortisone per $100 \mathrm{~g}$ body weight of fish, and transferred to 0,5 and $20 \mathrm{ppt}$ of $\mathrm{NaCl}$. Blood cortisol was $566 \mathrm{ng} / \mathrm{ml}$ at the beginning of the experiment (0h) but surged to $1250 \mathrm{ng} / \mathrm{ml}$ within $3 \mathrm{~h}$ in cortisol-injected fish. Cortisol levels were influenced not only by treatment but also by time, being higher at $3 \mathrm{~h}$ compared to $24 \mathrm{~h}$. Salinity level, time of exposure and their interaction, but not cortisol treatment, significantly affected plasma osmolality and the concentration of ions $\mathrm{Cl}^{-}$and $\mathrm{Na}^{+}$. This study showed that exogenous cortisol does not seem to play a significant role on the regulation of plasma osmolality and concentration of individual ions in pejerrey.
\end{abstract}

Keywords: pejerrey, Odontesthes bonariensis, cortisol, osmoregulation, salinity

\section{RESUMO}

Investigou-se a participação do cortisol na osmoregulação de peixe-rei Odontesthes bonariensis, em diferentes salinidades, em peixes adultos injetados com $0,7 \mathrm{mg}$ hidrocortisona por $100 \mathrm{~g}$ de peso corporal, e transferidos para 0, 5 e 20ppt de $\mathrm{NaCl}$. No inicio do experimento (Oh), o cortisol encontrado no plasma foi de 566ng/ml, aumentando para $1250 \mathrm{ng} / \mathrm{ml} \mathrm{em} 3 \mathrm{~h}$ em peixes injetados com cortisol. A concentração de cortisol foi influenciada não somente pelo tratamento, mas também pelo tempo, sendo maior 3 h após a inoculação, comparada à 24h. A salinidade, o tempo de exposição e a interação desses dois fatores, mas não o tratamento com o cortisol, afetaram significativamente a osmolaridade e a concentração dos ions $\mathrm{Cl}^{-}$e $\mathrm{Na}^{+}$do plasma. Este estudo mostrou que, o cortisol exógeno não influi significativamente na regulação da osmolaridade e da concentração de íons $\mathrm{Na}^{+}$e $\mathrm{Cl}^{-}$no plasma em peixe-rei.

Palavras-chave: peixe-rei, Odontesthes bonariensis, cortisol, osmorregulação, salinidade

\section{INTRODUCTION}

The pejerrey, Odontesthes bonariensis is an economically important atherinid fish from South America. Pejerrey is considered as a freshwater species because of its natural

Recebido em 12 de junho de 2006

Aceito em 14 de setembro de 2007

E-mail: mtsuzuki@cca.ufsc.br

Apoio: FAPESP, Ministry of Education, Science, Sports and

Culture of Japan (Monbusho) occurrence in inland waters, and introductions domestically and to other countries have been made almost entirely in fresh water. However, recent studies revealed better performance, in particular higher survival and growth rates, at salinities of 5 to 20 parts per thousand (ppt) compared to 0ppt (Tsuzuki et al., 2000a; 2001). 
It was also shown that pejerrey held in $0 \mathrm{ppt}$ presents basal levels of cortisol several-fold higher than those of typical freshwater species such as carp or tilapia (Tsuzuki et al., 2000b; 2001). Furthermore, pejerrey maintained in fresh water after stressful conditions such as transportation or handling had marked increases in blood cortisol, glucose and hematocrit values, and decreases in blood ions and osmolality, whereas fish transferred to higher salinity levels showed the opposite responses (Tsuzuki et al., 2001).

In most fish, cortisol has been found to be the most important corticosteroid in the circulation, playing an important role in the osmoregulatory process (Assem and Hanke, 1981; Morgan and Iwama, 1996; Sakamoto et al., 2001), and in the respiratory and intermediary metabolism (Chan and Woo, 1978; Boon et al., 1991; Morgan and Iwama, 1996). Cortisol has been regarded as a stress-related hormone (Schreck, 1981) as well as a seawater-adapting hormone, improving the hypoosmoregulatory ability in some teleost fish (Bisbal and Specker, 1991; Hwang and Wu, 1993). Cortisol stimulates $\mathrm{Na}^{+}-\mathrm{K}^{+}$-ATPase activity and influences water and electrolyte exchange in tissues (Forrest et al., 1973; Abo Hegab and Hanke, 1984; Madsen, 1990).

In studies with pejerrey, as previously cited (Tsuzuki et al., 2000b; 2001), cortisol levels were possibly affected not only by the stress of husbandry procedures, but also by salinity, making it impossible to establish a causal relationship between the changes in cortisol with those observed in glucose, ions and osmolality. Artificial elevation of blood cortisol levels has been regarded as an effective tool to isolate the effect of stress and investigate the role of cortisol in metabolism and osmoregulation in fish (Assem and Hanke, 1981; Hwang and Wu, 1993; Specker et al., 1994). Improvement of the hypoosmoregulatory ability occurred in the coastal cutthroat trout, Oncorhynchus clarki clarki parr (Morgan and Iwama, 1996), in the Atlantic salmon Salmo salar (Bisbal and Specker, 1991) and the rainbow trout, Oncorhynchus mykiss (Madsen, 1990). Cortisol injection increased ATPase activity and reduced the increases in plasma $\mathrm{Na}^{+}$in the stenohaline common carp, Cyprinus carpio, after transfer to a salinity of $15 \mathrm{ppt}$, whereas in the euryhaline tilapia, Oreochromis mossambicus
(=Sarotherodon mossambicus) exposed to 27ppt, it inhibited enzyme activity and had no effect on the $\mathrm{Na}^{+}$concentration (Abo Hegab and Hanke, 1984). In yearling coho salmon, Oncorhynchus kisutch, and in channel catfish, Ictalurus punctatus, cortisol treatment did not prevent changes in plasma osmolality and electrolyte concentrations in fresh water or during seawater acclimation (Redding et al., 1984; Eckert et al., 2001). Therefore, cortisol influence on the osmoregulatory process seems to differ widely among fish. No study on the physiology of cortisol has ever been conducted in atherinid fish.

Hence, the objective of the present study was to investigate the role of cortisol on the osmoregulation of adult pejerrey.

\section{MATERIAL AND METHODS}

Hatchery-reared adults (mean \pm SEM body weight of $237.6 \pm 2.3 \mathrm{~g}$ and total length of $31.6 \pm 0.1 \mathrm{~cm}$ ) were purchased from a commercial pejerrey fishfarm $^{1}$. Fish were raised and maintained in fresh water until the beginning of the experiment, except for a brief exposure to 5ppt during and immediately after transport from the farm to the laboratory at the Tokyo University of Marine Science and Technology, Japan. Fish were then allowed to acclimate to the experimental tanks (1801), at a density of $67 \mathrm{fish} / \mathrm{m}^{3}\left(16 \mathrm{~kg} / \mathrm{m}^{3}\right)$ for one week, at 0 ppt with constant flow. Fresh water was obtained by dechlorination of Tokyo city tap water through an activated charcoal filter. After filtration the water had the following characteristics: dissolved oxygen $=7.5 \mathrm{mg} / \mathrm{l}$, $\mathrm{pH}=7.8, \mathrm{NH} 4-\mathrm{N}<0.1 \mathrm{mg} / \mathrm{l}$, alkalinity $=44.4 \mathrm{mg} / \mathrm{l}$, total hardness $=70.1 \mathrm{mg} / \mathrm{l}$, non detectable levels of heavy metals $(\mathrm{Cu}, \mathrm{Cd}, \mathrm{Hg}, \mathrm{Se}, \mathrm{Cr}, \mathrm{Zn}, \mathrm{Fe}$. Se, $\mathrm{Pb}, \mathrm{As}), \mathrm{Na}^{+}=16.2 \mathrm{mg} / 1, \mathrm{Cl}^{-}=23.8 \mathrm{mg} / 1$, and free chlorine $=0.01 \mathrm{mg} / 1$.

Experimental salinities in the tanks were produced by dissolving $\mathrm{NaCl}$ in dechlorinated tap water and adjusted with an optical refractometer ${ }^{2}$ to the nearest $1 \mathrm{ppt}$. The rearing water during the experiment was daily exchanged at a make up rate of $50 \%$; this procedure ensured that unionised ammonia nitrogen was kept bellow $0.04 \mathrm{mg} / \mathrm{l}$. Constant temperature $\left(20.4 \pm 0.1^{\circ} \mathrm{C} ; \quad\right.$ mean \pm SEM $)$ and

\footnotetext{
${ }^{1}$ Yasuda Fish-Farm - Kumagaya, Saitama, Japan.

${ }^{2}$ Atago Co., Ltd. - Tokyo, Japan.
} 
natural photoperiod were used. Aeration was provided to maintain dissolved oxygen near saturation levels throughout the experiment.

Fish were fed to satiation once a day with a commercial diet for ayu. Feeding was discontinued $48 \mathrm{~h}$ prior to and during the experiment. Groups of control and cortisoltreated fish within the same salinity were distinctively tagged with subcutaneous implants of charcoal ink and stored in a communal tank to avoid differential handling- and tank-related bias. Fish were rapidly anesthetized with $0.7 \mathrm{ml} / 12$ phenoxyethanol for measurement, tagging and injection.

Cortisol was administered as a single injection bellow the pelvic fin since this form of administration elevated cortisol to desirable levels and resulted in less stress than abdominal pellet implantation in adult pejerrey (Tsuzuki, $2000)^{3}$. A dosage of $0.7 \mathrm{mg}$ hydrocortisone ${ }^{4}$ per $100 \mathrm{~g}$ of body weight of fish was delivered using $1 \%$ saline solution (SS) as a vehicle. It was found in preliminary trials that this dosage caused a surge in plasma cortisol consistent with that of stressed animals transferred to fresh water, i.e. maximum levels around $1200 \mathrm{ng} / \mathrm{ml}$, approximately $3 \mathrm{~h}$ after transfer (Tsuzuki et al., 2001). Injection volumes in all treatments were $0.2 \mathrm{ml}$ of vehicle per $100 \mathrm{~g}$ body weight.

Fish injected with SS only (control) and SS plus cortisol were immediately transferred to 0,5 and $20 \mathrm{ppt}$ in 1801 plastic tanks at a density of $16 \mathrm{~kg} / \mathrm{m}^{3}$. In order to verify if the injection itself had any effect on the parameters studied, additional groups of fish were sham-injected (only needle perforation) and non-injected (only handled) and then transferred to 0ppt.

Blood samples were taken from three to four fish in each group before, and at 3 and $24 \mathrm{~h}$ after injection and transfer to different salinities. Total blood (usually between 2-4ml) was drawn from caudal vessels into lithium-heparinized syringes. Plasma was extracted from theblood by centrifugation for $10 \mathrm{~min}$ at 3,000rpm and stored at $-85^{\circ} \mathrm{C}$ until analysis. Plasma cortisol levels were determined by a radioimmunoassay

\footnotetext{
${ }^{3}$ Tsuzuki, M.Y., preliminary results, 2000 - Tokyo University of Marine Science and Technology, Tokio, Japan.

${ }^{4}$ Sigma-Aldrish Co.- Tokyo, Japan.
}

procedure (I ${ }^{125}$ radioimmunoassay SPAC-S cortisol kit $)^{5}$. Plasma osmolality was measured by a vapour pressure osmometer (5500 vapour pressure osmometer ${ }^{6}$ and ions $\mathrm{Cl}^{-}$and $\mathrm{Na}^{+}$by ionmeter (CIM-104A ionmeter) ${ }^{7}$.

Data were analysed using a PROC MIXED in SAS (SAS/STAT software version 9, SAS Institute) by multifactorial analysis of variance (three-way ANOVA) to assess the significance of changes with cortisol treatment (yes or no), time of observation ( 3 and $24 \mathrm{~h})$, and salinity ( 0 , 5 and 20ppt) and their interactions. The significance of the differences between the group means was assessed by t-test $(\mathrm{P}<0.05)$. Results are expressed as mean \pm SEM.

\section{RESULTS AND DISCUSSION}

In the present study, mortality or differential behaviour was not observed in any of the cortisol or salinity treatments.

Plasma cortisol, osmolality, $\mathrm{Cl}^{-}$and $\mathrm{Na}^{+}$in shamand non-injected (only handled) fish showed the same trends as the control SS fish (Fig. 1 and 2) $(\mathrm{P}>0.05)$. Cortisol level, which was $566 \mathrm{ng} / \mathrm{ml}$ before the beginning of the experiment $(0 \mathrm{~h})$, increased to about $1250 \mathrm{ng} / \mathrm{ml}$ within $3 \mathrm{~h}$ in cortisol-injected fish regardless of salinity, and decreased at $24 \mathrm{~h}$ (Fig. 1). Only cortisol treatment and time affected blood cortisol levels (Tables 1 and 2).

However, while plasma cortisol attained the desired levels in cortisol-injected pejerrey, it had no noticeable effect on osmolality and ion levels at any of the salinities. Plasma osmolality and the concentration of ions $\mathrm{Cl}^{-}$and $\mathrm{Na}^{+}$in general showed similar trends, being affected by salinity, time and the interaction of salinity and time, but not by cortisol (Table 1). Osmolality values were higher at 20ppt, compared to 0 and 5ppt, at 3 and $24 \mathrm{~h}$. At 5 and $20 \mathrm{ppt}$, values at 3 and $24 \mathrm{~h}$ were statistically different, with maximum value at 24h $(\mathrm{P}<0.001)$ The same trend was found for $\mathrm{Cl}^{-}$ and $\mathrm{Na}^{+}$, although differences between 0 and 5 ppt were obtained at $24 \mathrm{~h}$ for these ions (Fig. 1; Table 3).

${ }^{5}$ Daiichi Radioisotope - Chiba, Japan.

${ }^{6}$ Wescor Inc. - Utah, USA.

${ }^{7}$ Shimadzu - Kyoto, Japan. 

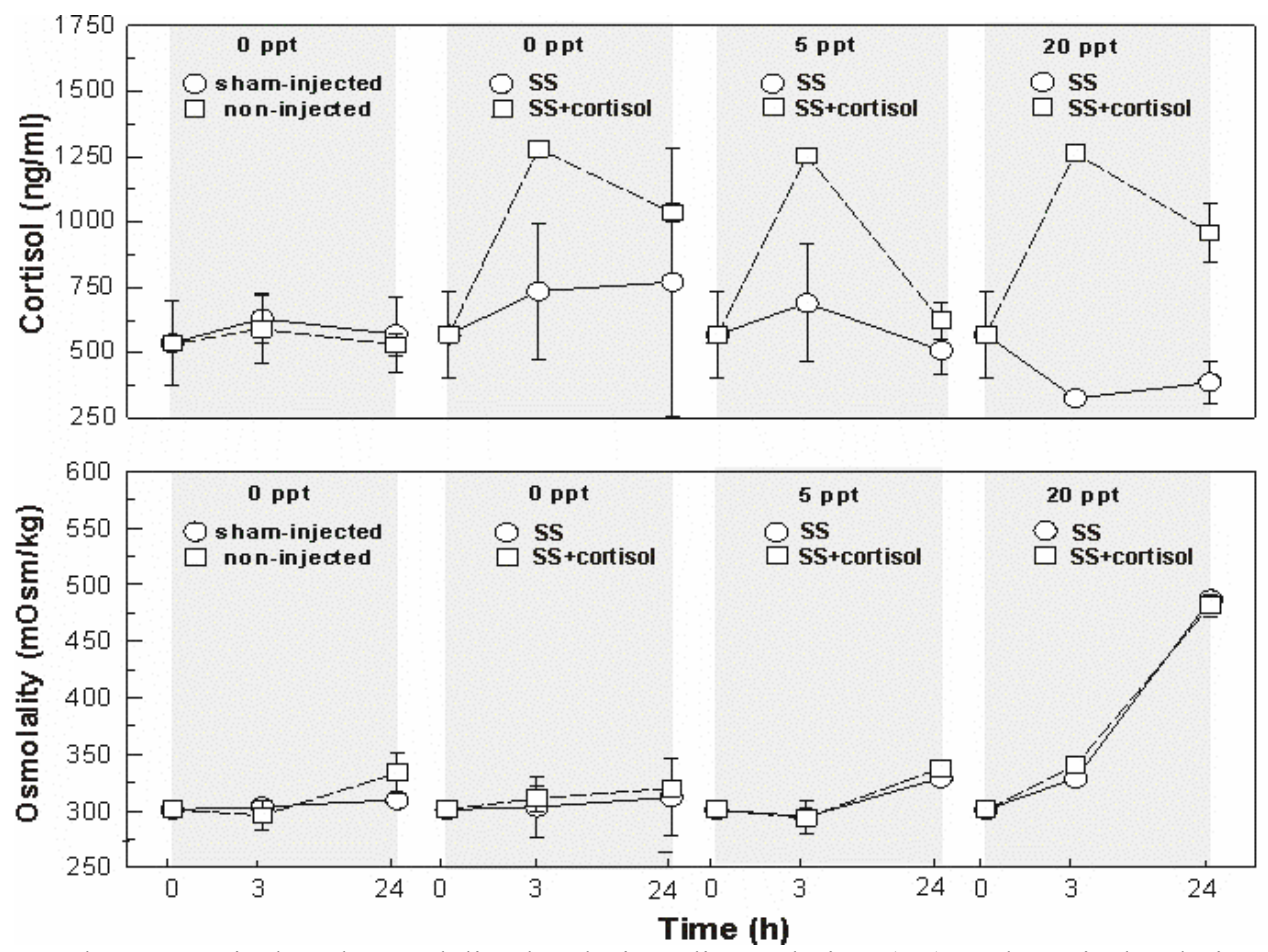

Figure 1. Plasma cortisol and osmolality levels in saline solution (SS) and cortisol solution injected, sham-injected and non-injected pejerrey transferred to 0,5 and 20ppt. Each point represents the mean \pm SEM.
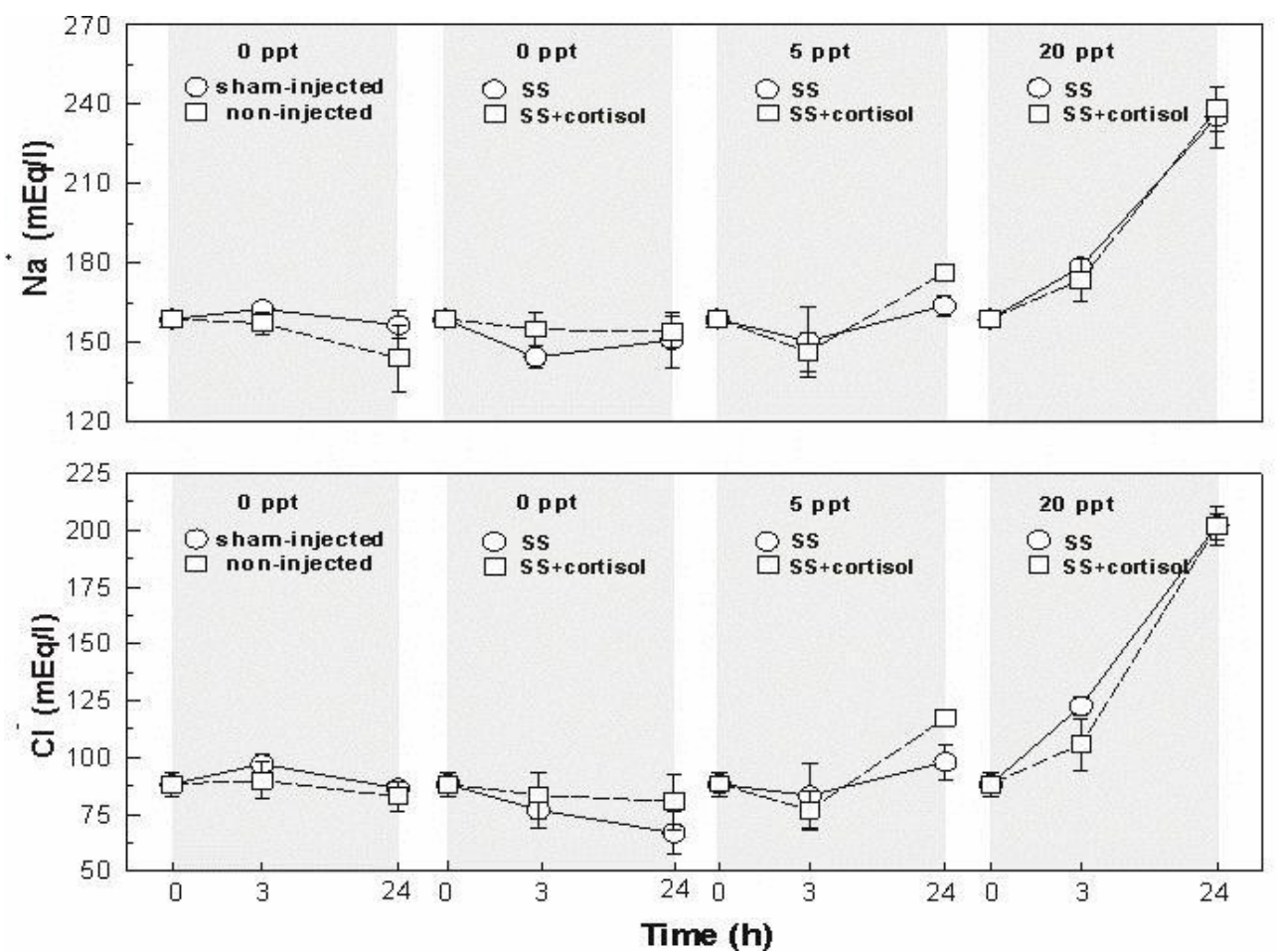

Figure 2. Plasma $\mathrm{Cl}^{-}$and $\mathrm{Na}^{+}$levels in saline solution (SS) and cortisol solution injected, sham-injected and non-injected pejerrey transferred to 0,5 and 20ppt. Each point represents the mean $\pm \mathrm{SEM}$. 
The significance of cortisol...

Table 1. Summary of the three-way analysis of variance for blood cortisol, osmolality and ions $\mathrm{Cl}^{-}$and $\mathrm{Na}^{+}$levels in pejerrey Odontesthes bonariensis

\begin{tabular}{lcccccccc}
\hline \multirow{2}{*}{ Effect } & \multicolumn{2}{c}{ Cortisol $(\mathrm{ng} / \mathrm{ml})$} & \multicolumn{2}{c}{ Osmolality $(\mathrm{mOsm} / \mathrm{kg})$} & $\mathrm{Cl}^{-}(\mathrm{mEq} / \mathrm{l})$ & \multicolumn{2}{c}{$\mathrm{Na}^{+}(\mathrm{mEq} / 1$} \\
\cline { 2 - 8 } & F-value & $\mathrm{Pr}>\mathrm{F}$ & $\mathrm{F}$-value & $\mathrm{PR}>\mathrm{F}$ & $\mathrm{F}$-value & $\operatorname{Pr}>\mathrm{F}$ & $\mathrm{f}$-value & $\mathrm{Pr}>\mathrm{F}$ \\
\hline Salinity & 2.42 & 0.1125 & 82.28 & $<0.0001$ & 73.82 & $<0.0001$ & 55.13 & $<0.0001$ \\
Time & 5.85 & 0.0243 & 83.49 & $<0.0001$ & 39.90 & $<0.0001$ & 37.38 & $<0.0001$ \\
Cortisol & 32.14 & $<0.0001$ & 0.81 & 0.3772 & 0.22 & 0.6467 & 0.52 & 0.4799 \\
Salinity and time & 1.18 & 0.3264 & 29.60 & $<0.0001$ & 22.85 & $<0.0001$ & 13.51 & 0.0002 \\
Salinity and cortisol & 2.21 & 0.1334 & 0.07 & 0.9314 & 1.00 & 0.3838 & 0.24 & 0.7894 \\
Time and cortisol & 4.18 & 0.0530 & 0.01 & 0.9182 & 2.09 & 0.1626 & 0.37 & 0.5506 \\
Salinity, time and cortisol & 0.08 & 0.9256 & 0.36 & 0.6985 & 0.22 & 0.8063 & 0.57 & 0.5719 \\
\hline
\end{tabular}

Table 2. Test for mean differences among time (h) and cortisol treatment for blood cortisol in pejerrey Odontesthes bonariensis

\begin{tabular}{cccc}
\hline Time $(\mathrm{h})$ & Cortisol treatment & DLSM $^{1}$ & Probability $^{2}$ \\
\hline $3 \times 24$ & & 204.9 & $<0.0001$ \\
& no X yes & -527.7 & $<0.0001$ \\
\hline
\end{tabular}

${ }^{1}$ DLSM $=$ differences of least squares means; ${ }^{2}$ Probability value for DLSM among time or cortisol treatment in blood cortisol level.

Table 3. Test for mean differences among time (h) and salinity (ppt) for blood osmolality, $\mathrm{Cl}^{-}$and $\mathrm{Na}^{+}$in pejerrey Odontesthes bonariensis.

\begin{tabular}{cccccccc}
\multirow{2}{*}{ Salinity } & \multirow{2}{*}{ Time } & \multicolumn{2}{c}{ Osmolality } & \multicolumn{2}{c}{$\mathrm{Cl}^{-}$} & \multicolumn{2}{c}{$\mathrm{Na}^{+}$} \\
\cline { 3 - 7 } & & DLSM $^{1}$ & Probability & DLSM & Probability & DLSM & Probability \\
\hline 0 & 3 X 24 & -9.1 & 0.3806 & -5.2 & 0.5994 & -2.8 & 0.7157 \\
5 & 3 X 24 & -38.9 & 0.0003 & -26.0 & 0.0134 & -20.7 & 0.0105 \\
20 & 3 X 24 & -149.8 & $<0.0001$ & -87.8 & $<0.0001$ & -60.7 & $<0.0001$ \\
0 X 5 & 3 & 13.0 & 0.1433 & 0.1 & 0.9887 & 1.2 & 0.8624 \\
0 X 5 & 24 & -16.7 & 0.1020 & -31.0 & 0.0056 & -16.7 & 0.0437 \\
0 X 20 & 3 & -27.3 & 0.0068 & -34.1 & 0.0011 & -26.3 & 0.0011 \\
0 X 20 & 24 & -168.0 & $<0.0001$ & -127.0 & $<0.0001$ & -84.2 & $<0.0001$ \\
5 X 20 & 3 & -40.3 & 0.0001 & -34.2 & 0.0011 & -27.6 & 0.0007 \\
5 X 20 & 24 & -151.3 & $<0.0001$ & -96.0 & $<0.0001$ & -67.5 & $<0.0001$ \\
\hline
\end{tabular}

${ }^{1}$ DLSM $=$ differences of least squares means. ${ }^{2}$ Probability value for DLSM among levels of salinity or time for osmolatity, $\mathrm{Cl}^{-}$or $\mathrm{Na}^{+}$.

The lower cortisol levels at 5 and 20ppt after stress of transport or crowding of adult pejerrey as observed in previous studies (Tsuzuki et al., 2001) were possibly due to a natural preference for higher salinity levels, resulting in decreased cortisol secretion, or increased clearance rates, as pointed out by Goswami et al. (1983), Redding et al. (1984) and Nichols and Weisbart (1985). Data on the survival and growth of pejerrey larvae and adults at different salinities seemed to support the first hypothesis as both were shown to be euryhaline and to perform better at salinities close to 20ppt, especially compared to $0 \mathrm{ppt}$ (Tsuzuki et al., 2000a). This notion was reinforced by information on the natural distribution of this species, which, although continental, coincides with areas where surface and ground water have substantial salinity (Mc Donagh, 1934; Ringuelet et al., 1967; Saravia et al., 1987).

However, in these studies with pejerrey, cortisol levels were possibly affected by a synergic effect of the stress of husbandry procedures and salinity, making it difficult to evaluate the effect of cortisol on individual ions and osmolality. In this way, one hypothesis tested here was that the artificial elevation of the blood cortisol level would prevent or at least mitigate the increases in plasma osmolality and individual electrolyte concentrations at higher salinity levels, such as 20ppt. Cortisol implantation has been used to demonstrate that cortisol potentiates hypoosmoregulatory ability in some salmonids, 
tilapia and medaka (Bisbal and Specker, 1991; Hwang and Wu, 1993; Sakamoto et al., 2001). Single injection of cortisol at similar doses used in this study, also influenced the respiratory and intermediary metabolism in other species (Abo Hegab and Hanke, 1984; Chan and Woo, 1978).

In the present experiment, it is possible that other hormones are involved in the osmoregulation of O. bonariensis as cortisol treatment did not affect plasma osmolality and individual ions, fact also observed in channel catfish transferred to hyperionic salt water (Davis and Simco, 1976; Eckert et al., 2001) and in coho salmon during seawater acclimation (Redding et al., 1984). These last authors suggested that other factors in addition to cortisol might be required to activate ion transport mechanisms in coho salmon. Subsequently, physiological roles for catecholamine, thyroxine, cortisone and growth hormone during saltwater acclimation have been proposed in other species (Mazeaud and Mazeaud, 1981; Dangé, 1986; Patiño et al., 1987; Madsen, 1990). For instance, increased demineralization caused by catecholamine action on ionic transfer across the gills was observed in mullet subjected to salt water stress (Pic et al., 1975). Likewise, Dangé (1986) observed that the ability of cortisol to stimulate branchial $\mathrm{Na}^{+}-\mathrm{K}^{+}$ATPase activity in tilapia was augmented by thyroxine in hyperosmotic conditions whereas Madsen (1990) indicated that cortisol and growth hormone are synergistically involved in the transition to hypoosmoregulation in sea trout parr, Salmo trutta trutta.

In contrast to the lack of an effect on osmolality and ions in this experiment, previous studies have shown a close association of glucose and cortisol levels in pejerrey (Tsuzuki et al., 2000b; 2001) in which endogenous cortisol was measured. Cortisol is assigned to have a stimulatory effect on liver gluconeogenesis, elevating blood sugar levels (Wedemeyer et al., 1990; Boon et al., 1991), possibly providing readily accessible energy for osmoregulation (Assem and Hanke, 1979a,b; Abo Hegab and Hanke, 1982; 1984). It is not clear if this is the case with pejerrey since, as discussed above, there were no noticeable changes in ionic and osmotic parameters that could be associated with cortisol and hence with glucose, nor did the cortisol/glucose availability prevent the surge in blood ions at $20 \mathrm{ppt}$. Thus, it appears more likely that the elevated glucose levels observed as a result of elevations in cortisol levels are associated with other stressful situations such as predator avoidance, counter current swimming and other behaviours where glucose is necessary for muscle activity. This could be a further indication that cortisol, at least alone, is not directly implicated in osmoregulation in pejerrey as discussed previously.

In conclusion, this study showed that exogenous cortisol does not seem to play a significant role on the regulation of plasma osmolality and concentration of individual ions. It is suggested that other factor(s) (perphaps, other hormones acting in conjunction with cortisol) may be required to activate ion transport mechanisms.

\section{ACKNOWLEDGMENTS}

The senior author was supported by allowances from the Ministry of Education, Science, Sports and Culture of Japan (Monbusho) and Fundação de Amparo à Pesquisa do Estado de São Paulo (Fapesp, Brazil), which are gratefully acknowledged.

\section{REFERENCES}

ABO HEGAB, S.; HANKE, W. Electrolyte changes and volume regulatory processes in carp (Cyprinus carpio) during osmotic stress. Comp. Biochem. Physiol., v.71, p.157-164, 1982 .

ABO HEGAB, S.; HANKE, W. The significance of cortisol for osmoregulation in carp (Cyprinus carpio) and tilapia (Sarotherodon mossambicus). Gen. Comp. Endocrinol., v.54, p.409-417, 1984.

ASSEM, H.; HANKE, W. Concentration of carbohydrates during osmotic adjustment of euryhaline teleost, Tilapia mossambica. Comp. Biochem. Physiol., v.64, p.5-16, 1979a.

ASSEM, H.; HANKE, W. Volume regulation of muscle cells in the euryhaline teleost, Tilapia mossambica. Comp. Biochem. Physiol., v.64, p.17-23, 1979 b.

ASSEM, H.; HANKE, W. Cortisol and osmotic adjustment of the euryhaline teleost, Sarotherodon mossambicus. Gen. Comp. Endocrinol., v.43, p.370-380, 1981.

BISBAL, G.A.; SPECKER, J.L. Cortisol stimulates hypoosmoregulatory ability in Atlantic salmon, Salmo salar L. J. Fish Biol., v.9, p.421-432, 1991. 
BOON, J.V.D.; GUIDO, E.E.J.M.; THILLART, V.D. et al. The effects of cortisol administration on intermediary metabolism in teleost fish. Comp. Biochem. Physiol., v.100, p.47-53, 1991.

CHAN, D.K.O.; WOO, N.Y.S. Effect of cortisol on the metabolism of the eel, Anguilla japonica. Gen. Comp. Endocrinol., v.35, p.205-215, 1978.

DANGÉ, A.J. Branchial Na+-K+-ATPase activity in freshwater of saltwater acclimated tilapia, Oreochromis (Sarotherodon) mossambicus: effects of cortisol and thyroxine. Gen. Comp. Endocrinol., v.62, p.341-343, 1986.

DAVIS, K.B.; SIMCO, B.A. Salinity effects on plasma electrolytes of channel catfish, Ictalurus punctatus. $J$. Fish. Res. Board Can., v.33, p.741-746, 1976.

ECKERT, S.M.; YADA, T.; SHEPHERD, B.S. et al. Hormonal control of osmoregulation in the channel catfish Ictalurus punctatus. Gen. Comp. Endocrinol., v.122, p.270-286, 2001.

FORREST, J.N. Jr.; COHEN, A.D.; SCHON, D.A. et al. $\mathrm{Na}$ transport and Na-K-ATPase in gills during adaptation to seawater: effects of cortisol. Am. J. Physiol., v.224, p.709-713, 1973.

GOSWANI, S.V.; PARWEZ, I.; SUNDARARAJ, B.I. Some aspects of osmoregulation in a stenohaline freshwater catfish, Heteropneustes fossilis (Bloch), in different salinities. J. Fish Biol., v.23, p.475-487, 1983.

HWANG, P.P.; WU, S.M. Role of cortisol in hypoosmoregulation in larvae of the tilapia (Oreochromis mossambicus). Gen. Comp. Endocrinol., v.92, p.318-324, 1993.

MAC DONAGH, E.J. Nuevos conceptos sobre la distribuitión geográfica de los peces Argentinos baseado en expediciones Del Museo de La Plata. Rev. Mus. La Plata, v.34, p.21-188, 1934 (in Spanish).

MADSEN, S.S. The role of cortisol and growth hormone in seawater adaptation and development of hypoosmoregulatory mechanisms in sea trout parr (Salmo trutta trutta). Gen. Comp. Endocrinol., v.71, p.1-11, 1990.

MAZEAUD, M.M.; MAZEAUD, F. Adrenergic responses to responses to stress in fish. In: PICKERING, A.D. (Ed.). Stress in fish. London: Academic Press,1981. p.49-76.

MORGAN, J.D.; IWAMA, G.K. Cortisol-induced changes in oxygen consumption and ionic regulation in coastal cutthroat trout (Oncorhynchus clarki clarki) parr. Fish Physiol. Biochem., v.15, p.385-394, 1996.

NICHOLS, D.J.; WEISBART, M. Cortisol dynamics during seawater adaptation of Atlantic salmon, Salmo salar. Am J Physiol., v.248, p.651-659, 1985.

PATIÑO, R.; REDDING, J.M.; SCHRECK, C.B. Interrenal secretion of corticosteroids and plasma cortisol and cortisone concentrations after acute stress and during seawater acclimation in juvenile coho salmon (Oncorhynchus kisutch). Gen. Comp. Endocrinol., v.68, p.431-439, 1987.

PIC, P.; MAYER-GOSTAN, N.; MAETZ, J. Branchial effects of epinephrine in the seawater-adapted mullet. II. $\mathrm{Na}^{+}$and $\mathrm{Cl}^{-}$extrusion. Am. J. Physiol., v.228, p.441-447, 1975.

REDDING, J.M.; SCHRECK, C.B.; BIRKS, E.K. et al. Cortisol and its effects on plasma thyroid hormone and electrolyte concentration in fresh water and during seawater acclimation in yearling coho salmon, Oncorhynchus kisutch. Gen. Comp. Endocrinol., v.56, p.146-155, 1984.

RINGUELET, R.A.; SALIBIÁN, A.; CLAVÉRIE, E. et al. Limnologia química de las lagunas pampasicas (Provincia de Buenos Aires). Physis, v.74, p.201-221, 1967

SARAVIA, J.R.; BENAVIDEZ, R.; CANZIANI, O. et al. Lineamentos generales y regionales para um plan maestro de ordenamiento hídrico del território bonaerense, Convenio MOSP Nacíon-Provincia de Buenos Aires, 1987. 313p.

SAKAMOTO, T.; KOZAKA, T.; TAKAHASHI, A. et al. Medaka Oryzias latipes as a model for hypoosmoregulation of euryhaline fishes. Aquaculture, v.193, p.347-354, 2001.

SCHRECK, C.B. Stress and compensation in teleostean fishes: responses to social and physiological factors. In: PICKERING, A.D. (Ed.). Stress in fish. New York: Academic Press, 1981. p.295-321.

SPECKER, J.L.; PORTESI, D.M.; CORNELL, S.C. et al. Methodology for implanting cortisol in Atlantic salmon and effects of chronically elevated cortisol on osmoregulatory physiology. Aquaculture, v.121, p.181193, 1994.

TSUZUKI, M.Y.; AIKAWA, H.; STRÜSSMANN, C.A. et al. Comparative survival and growth of embryos, larvae, and juveniles of pejerrey Odontesthes bonariensis and $O$. hatcheri at different salinities. J. Appl. Ichthyol., v.16, p.126-130, 2000a.

TSUZUKI, M.Y.; AIKAWA, H.; STRÜSSMANN, C.A. et al. Physiological responses to salinity increases in the freshwater silversides Odontesthes bonariensis and $O$. hatcheri (Pisces, Atherinidae). Rev. Bras. Oceanogr. (Braz. J. Oceanogr.), v.48, p.81-85, 2000 b.

TSUZUKI, M.Y.; OGAWA, K.; STRÜSSMANN, C.A. et al. Physiological responses after stress and subsequent recovery at different salinities in adults pejerrey Odontesthes bonariensis. Aquaculture, v.200, p.349-362, 2001.

WEDEMEYER, G.A.; BARTON, B.B.; MCLEY, D.J. Stress and acclimation. In: SCHRECK, C.B.; MOYLE, P.B. (Eds). Methods for Fish Biology. Bathesda: American Fisheries Society, 1990. p.451-477. 